ICACCG2020 30-31 July, 2020, Ansal University, Gurgaon, India

International Journal of Technical Research \& Science (Special Issue)

ISSN No.:2454-2024 (online)

\title{
REVIEW OF SUSTAINABLE BUILDING MATERIALS FOR CONSTRUCTION INDUSTRY
}

\author{
Satyam Kumar ${ }^{1}$, Vishal Puri ${ }^{2}$, M. L. Aggarwal ${ }^{3}$ \\ E-Mail Id: ${ }^{1}$ kumar.satyam2609@ gmail.com, ${ }^{2}$ vpuri@ jcboseust.ac.in, ${ }^{3}$ aggarwalmlal@ rediffmail.com \\ Department of Civil Engineering, JCBUST YMCA, Faridabad, Haryana, India
}

\begin{abstract}
In any construction activity, the material is an essential component. But in construction, there is a large dependency on man-made materials as compared with materials from natural resources. Manufacturing of manmade building materials emits a large amount of $\mathrm{CO} 2, \mathrm{CO}, \mathrm{NO} 2$, and other environmentally unfriendly gasses and by-products which may be poisonous and harmful for human health as well as for the environment. Because of this infrastructure sector is one of the leading causes of environmental degradation. With drastic exposure in population in recent times, the demand for these man-made materials has been increased a lot. To meet this need of the current situation, we have to look for sustainable, eco-friendly materials that have characteristics like energy efficiency, easy availability, and not disturbing towards environment ecology system. The main aim of these green building materials is to reduce the impact of construction activities on human health and the natural environment. This current paper reviews the impact of sustainable green building material on the environment, its properties, and its benefits. Different types of green building material and their characteristics and specifications. In this, a comparison between green building and conventional building on various conditions is also discussed. Further, we have also reviewed U.S. green building rating systems (LEED) and its criteria for certification.
\end{abstract}

Keywords: Conventional Building, Energy Efficiency, Green Material, LEED, Sustainability.

\section{INTRODUCTION}

The production of greenhouse gasses increases day by day. The major producer of these harmful gasses is the building industry as cement manufacturing produces about $8 \%$ of the world's carbon dioxide (CO2). Alone $\mathrm{CO} 2$ produced by cement manufacturing can beat the whole china and U.S.A. contribution in CO2 production [1]. So from the environmental point of view, it is seen that the construction sector needs more sustainable methods. The basic concept behind the introduction of sustainable methods is to improve the quality of life. Building sector individuals start paying attention to sustainability during designs and construction. Their objective is to reduce the overall impact of greenhouse gasses for better health of humans and the environment. The history of sustainability involves the ecological system from earlier civilizations which are dominated by humans. In the earlier civilization, different countries have different sustainable methods developed in which china had concentrated solar power for heat energy, America was using hot spring as the replacement of geothermal sources and Egypt was using wind energy for their energy production (Pyramid is the evidence of it). During the period of the industrial revolution there was a need for abundant energy sources. So coal was used in spite of knowing the fact that it produces a lot of greenhouse gasses. But in the year 1970, when the energy crisis occurred sustainable methods started establishing their existence in the practical world. That is why they were being moved to industrial use from laboratories. After that builders and designers started providing their maximum efforts to decrease the dependence of the building sector on fossil fuels. To decrease these dependence builders started looking for various energy substitutes and new building materials which made building sector eco-friendlier so-called "Sustainable Buildings". After this, a new competition raised between the companies to verify their methods, materials, and practices in a more precise and efficient way. In recent days, green buildings make its existence widely to check over the production of greenhouse gases by building sectors. For this check-up, the U.S. Green building council was founded whose aim was to check the maximum sustainability in building construction. In nowadays not only industries but also societies started practicing energy-efficient methods for saving money, energy, and reducing the production of wastes [2]. This paper presents the requirement and needs of different sustainable materials and techniques useful for making construction eco-friendly.

\section{GREEN MATERIAL AND ITS SPECIFICATIONS}

The construction industry is the major industry of any nation that uses most amounts of energy and natural resources. If we talk about the exact amount of energy utilization, the construction industry utilizes $60 \%$ of the raw material, and $60 \%$ of the nation's surplus and non-hazardous wastes are produced by this sector [1]. For the reduction in the production of these hazardous wastes, some new materials are widely used which is commonly known as green materials. A small comparison between green building and the conventional building is shown in Figure2.1. As per a study carried out by Lucy Wang [3], shows that conventional building is made from bricks and concrete. It has insulation from foam bread and thermal wrap. In Green building, the structure is made up of straw bales, stone, timber frame, and having insulation with wool and wood fiber. These materials are selected on the basis of its properties like recyclability, reusability, and less production of wastes. In fact, the production of green building materials and reusing them not only saves energy but also reduces greenhouse gasses, and also there is a reduction in 
ICACCG2020 30-31 July, 2020, Ansal University, Gurgaon, India

International Journal of Technical Research \& Science (Special Issue)

ISSN No.:2454-2024 (online)

transportation and shipping costs because of its easy availability [4]. These green building materials have properties like Renewability, Reusability, Easy availability, high energy efficiency, and Low/Non-toxic nature [5]. So, now the question arises what are the few building materials which are substitute to the conventional material. In the upcoming section few green building materials such as earthen structures, straw bale, ICF, etc. are discussed in detail which includes its application, advantage, and limitations.

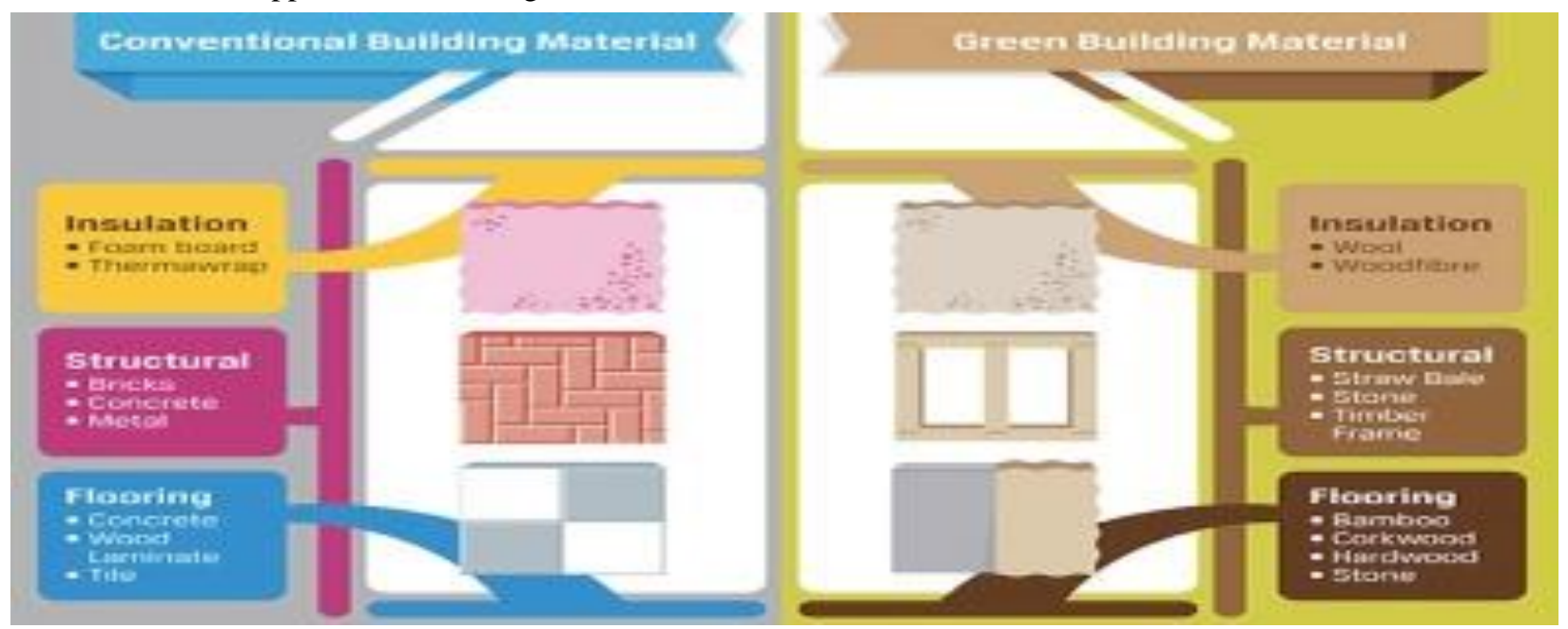

Fig. 2.1 Material Comparison [3]

\subsection{Alternative Traditional Building Materials}

\subsubsection{Earthen Structures}

The earthen structure is the building or structure made from soil dirt, clay, gravel, and lime. This is the traditional material that is being used from prehistoric times. According to recent statistics, the percentage of earthen houses will be around $50 \%$ in the next 15 years as per the study conducted by Niroumand, $\mathrm{H}$ [6]. The construction of buildings by using rammed-earth, adobe, and other earthen materials is considered as the best evergreen material. These materials have benefits in costs, aesthetics, acoustics and heat insulation, and low energy consumption. However, few limitations include weak earthquake wearing forces. But still, strength can be increased by adding bamboo, canes as beams and pillars for an extra [8]. In Figure 2.2, an earthen building is shown which is made up of soil dirt, clay, gravel, and lime. This type of buildings has traditional pieces of evidence as it is still used in modern houses. As per the record of Down to Earth magazine, India has 65 million mud houses out of 118 million total houses [9].

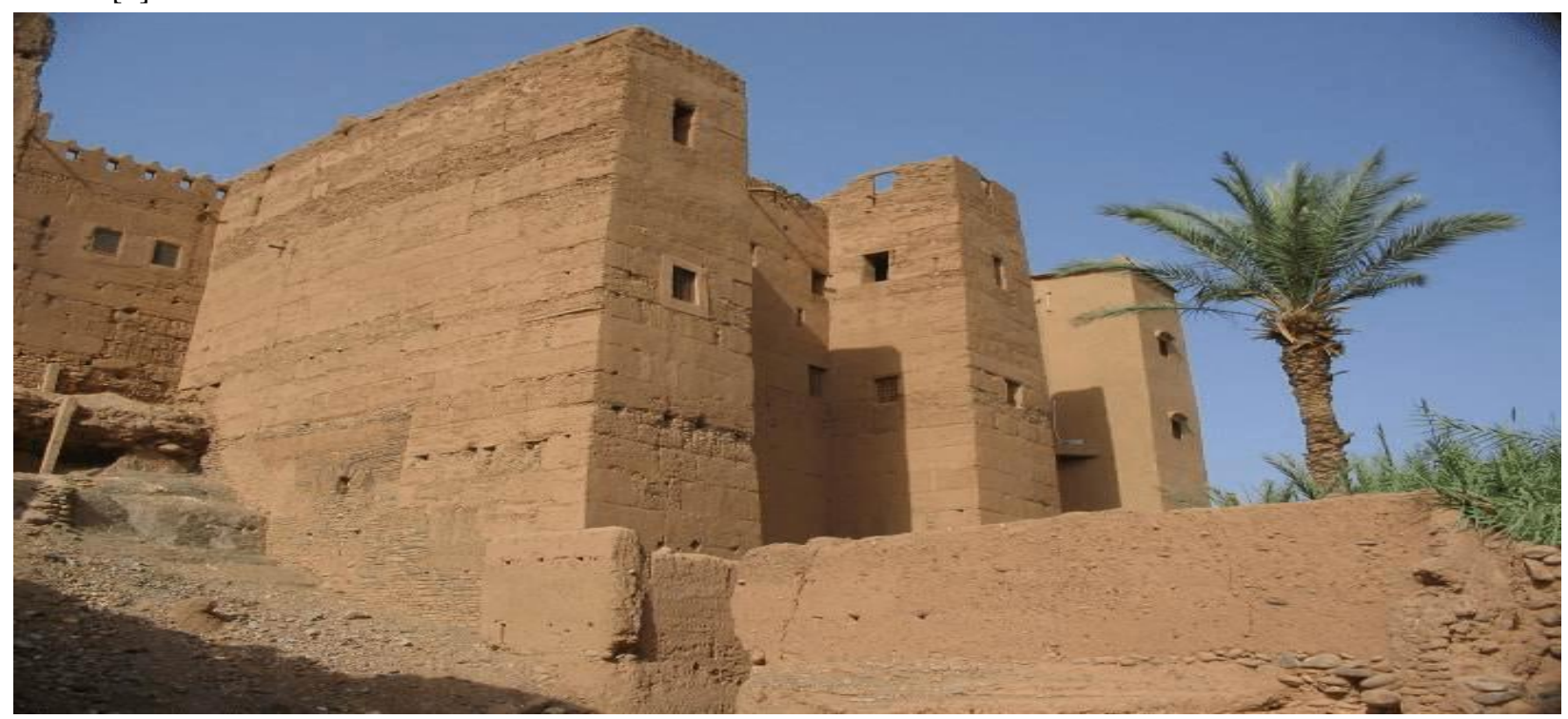

Fig. 2.2 Earthen Structure [7]

\subsubsection{Straw Bale}

Straw is a fibre obtained from nature as a by-product of agriculture. It is composed of cellulose, hemicellulose, lignin, and silica. Among straw bales, rice straw bales are considered to be the toughest ones due to high silica content [10]. Straw bales are considered to be the waste material and if burned in the environment produces harmful gasses, so it is better to use it as a building material. A study shows that it is environment friendly in its production, placement, and maintenance. Figure 2.3 shows a house made up of straw. In this, we can see walls of the building are 
ICACCG2020 30-31 July, 2020, Ansal University, Gurgaon, India

International Journal of Technical Research \& Science (Special Issue)

ISSN No.:2454-2024 (online)

made up of straw bales and wooden framework for extra support. Straw bales buildings were first discovered by the settlers of the sandhill region of Nebraska [12]. It has many advantages such as low cost, easy to install, cost efficiency and it is fully biodegradable [13]. It has certain limitations such as high exposure to fire, thick wall width which means that most of the area is un-usable.

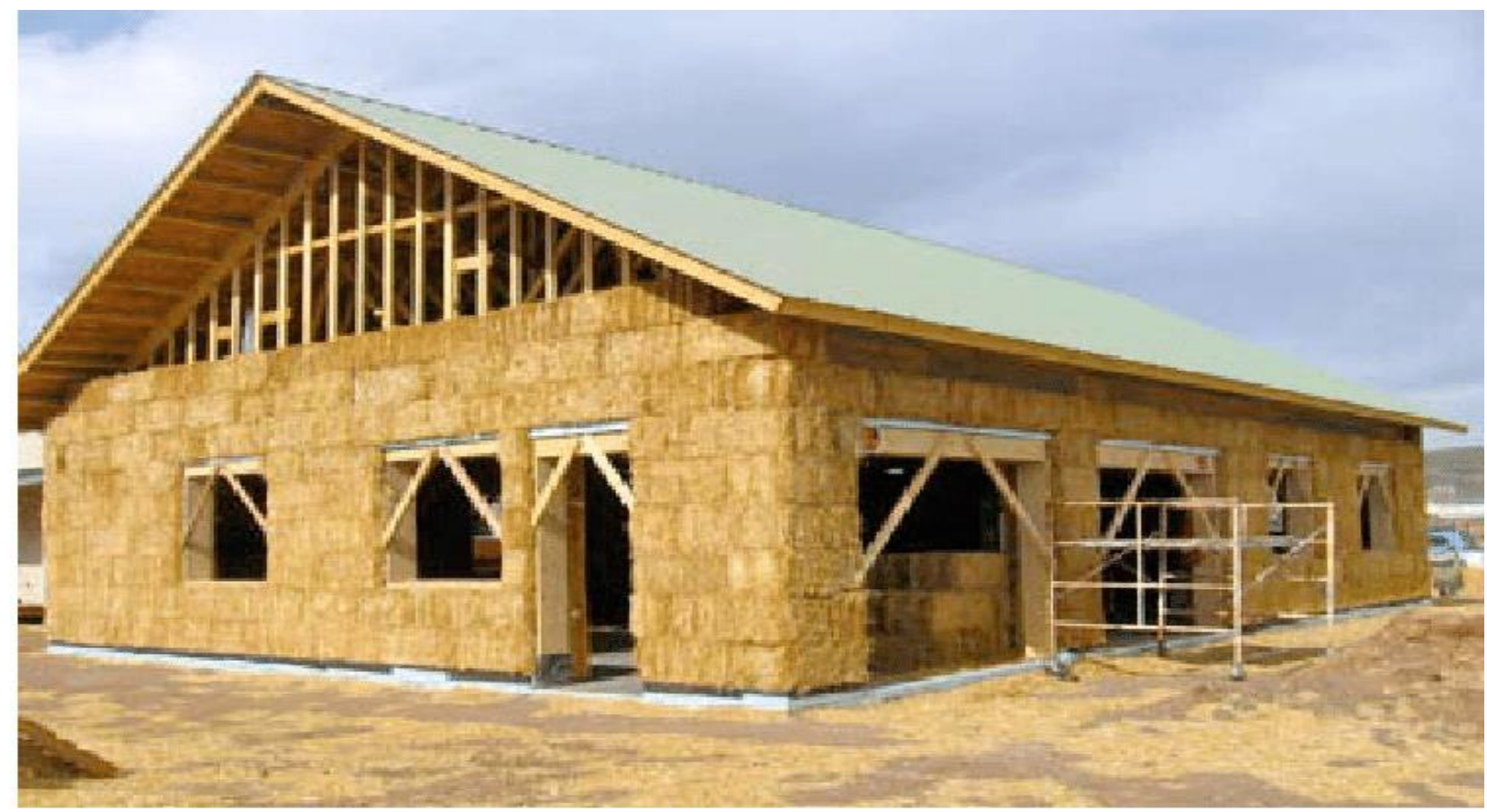

Fig.2.3 Straw Bale House [11]

\subsubsection{Insulated Concrete Forms (ICF)}

In insulated concrete forms, concrete walls are sandwiched between the layers of insulation materials. This system is energy efficient and also provides strength to the walls. It is a green material that is known for its durability and longevity. It is used as a building material mainly in low rise buildings of residential and commercial use. In the year 2001, research was done by the U.S. Department of Housing and Urban Development in which it was found that its cost is about 3 to $5 \%$ more than a conventional building [14]. But except for cost, there are many performance benefits like fire resistivity, energy efficiency, etc. Figure 2.4 shows a model of building constructed by using insulated concrete forms (ICF).

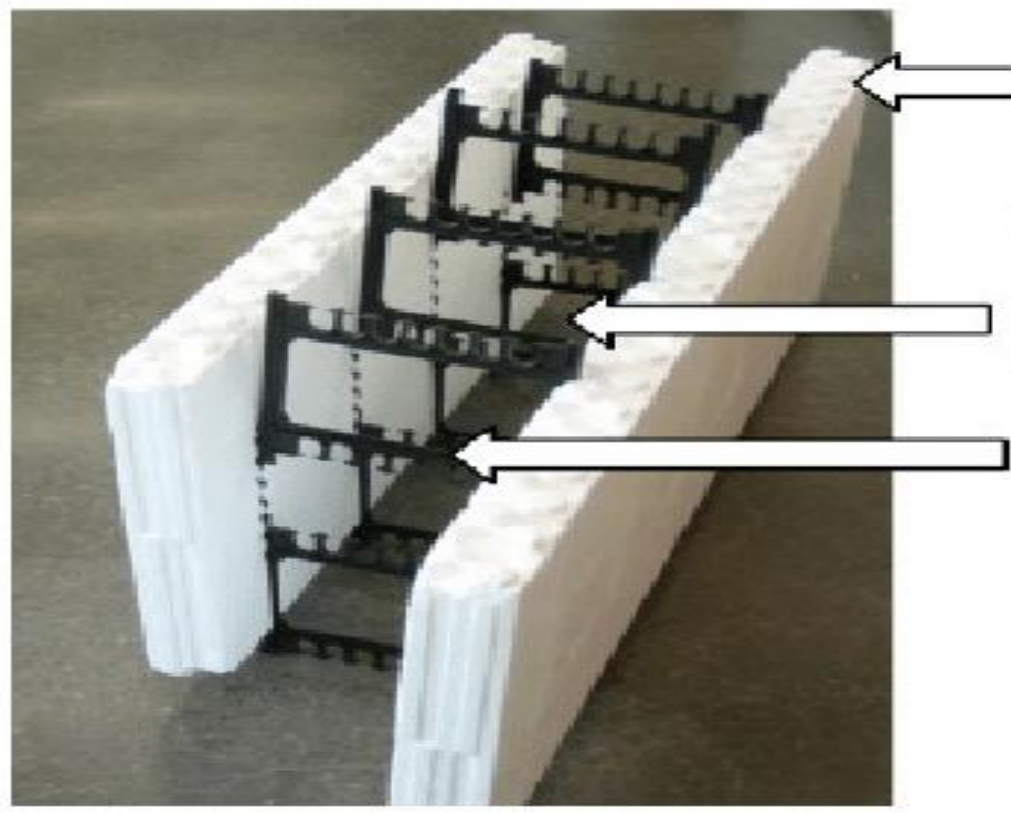

\section{Polystyrene Form}

Concrete Poured in between ties Polypropylene ties

Fig.2.4 Insulated Concrete Forms Walls [15]

\subsubsection{Structural Insulated Pannels (SIPS)}

SIPS are insulated panels in which foam insulation is sandwiched between the sheets of Oriented Strand Boards. It is 
ICACCG2020 30-31 July, 2020, Ansal University, Gurgaon, India

International Journal of Technical Research \& Science (Special Issue)

ISSN No.:2454-2024 (online)

constructed in industries and is a large panel of 24'x8'. An image installation of the same structural insulated panels is shown in figure 2.5. Board can be made up of sheet metal or wood or even from cement also. It might have a little higher cost but is beneficial in the long run [16]. It consumes less time in installation as it is directly available as ready to use the material. It also consumes very less energy in operation. In research, it was found that the buildings made by using SIPs are $40 \%$ more economically beneficial than traditional buildings.

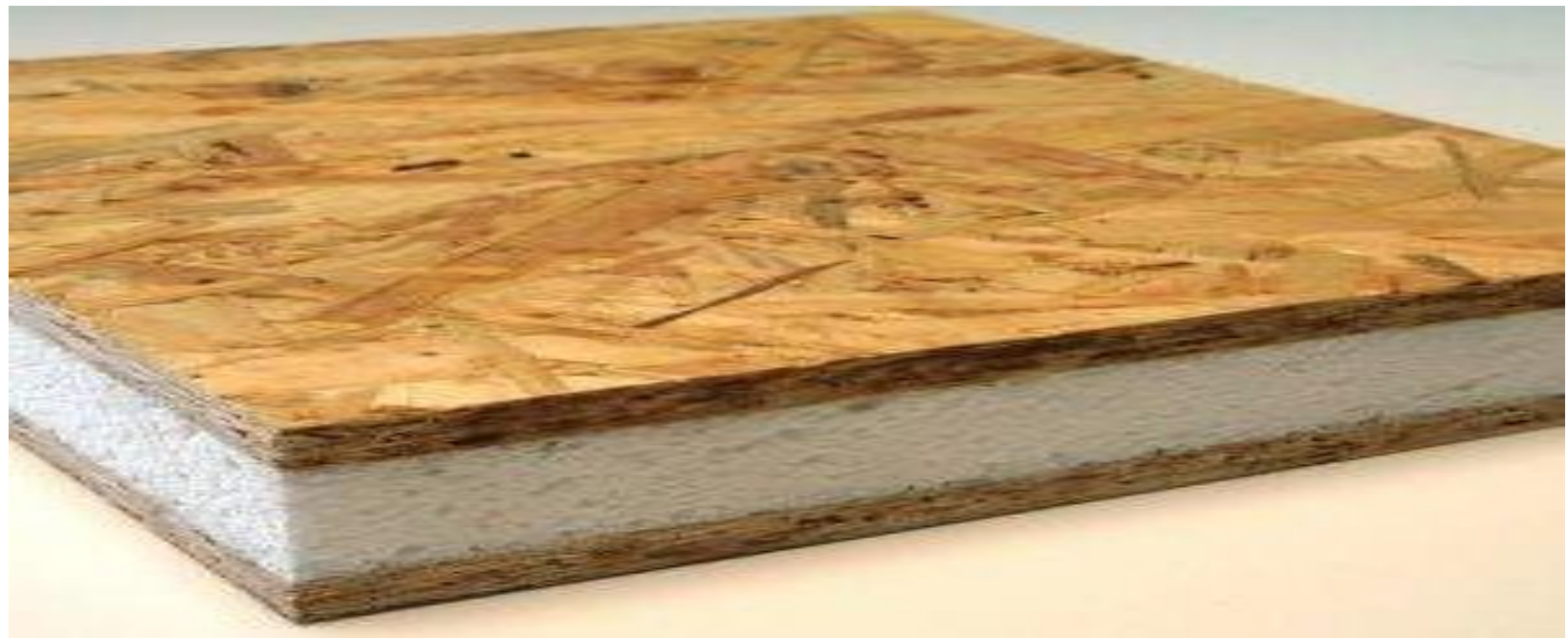

Fig. 2.5 Structural Insulated Panels [17]

\subsubsection{Wood}

Woods is one of the best green materials which are traditional too [18]. In Green, building wood is classified into two types i.e. Engineered wood and wood certified by different countries. Engineered wood is widely used in both traditional and greenhouses. In figure 2.6, wood scraps are used for construction which gives even more strength than sawn logs. Wooden houses gain their popularity because of the easy availability of wood and can be tied quickly with the help of simple tools only.

So, on the basis of the properties of these materials, we can conclude that earthen materials can be used in hot areas because it provides good heat insulation. But it cannot be used in high prone seismic zone areas because of its weak earthquake wearing forces. In the seismic zone, if we use earthen material then extra support is needed by bamboo, canes, etc. Strawbale can be used in open humid areas because of having good air inflow through pores of the straw bale wall. But it is needed to protect it from fire exposure because of its low combustion temperature. Insulated concrete forms and structural insulated panels are widely used because of its thermal insulation and U.V. ray insulation to protect it from heat rays. Wooden houses are the best and widely used green building material because of its local availability and easy installation properties. In terms of price, it might be costlier but will give high returns in the long term. After construction, a green building needs to be evaluated. There are few agencies which provide certifications to green building like IGBC is a certification agency of India. The certification agency of the U.S.A. (USGBC) is considered to be the best and is widely accepted. USGBC established LEED for certification is discussed below in detail.

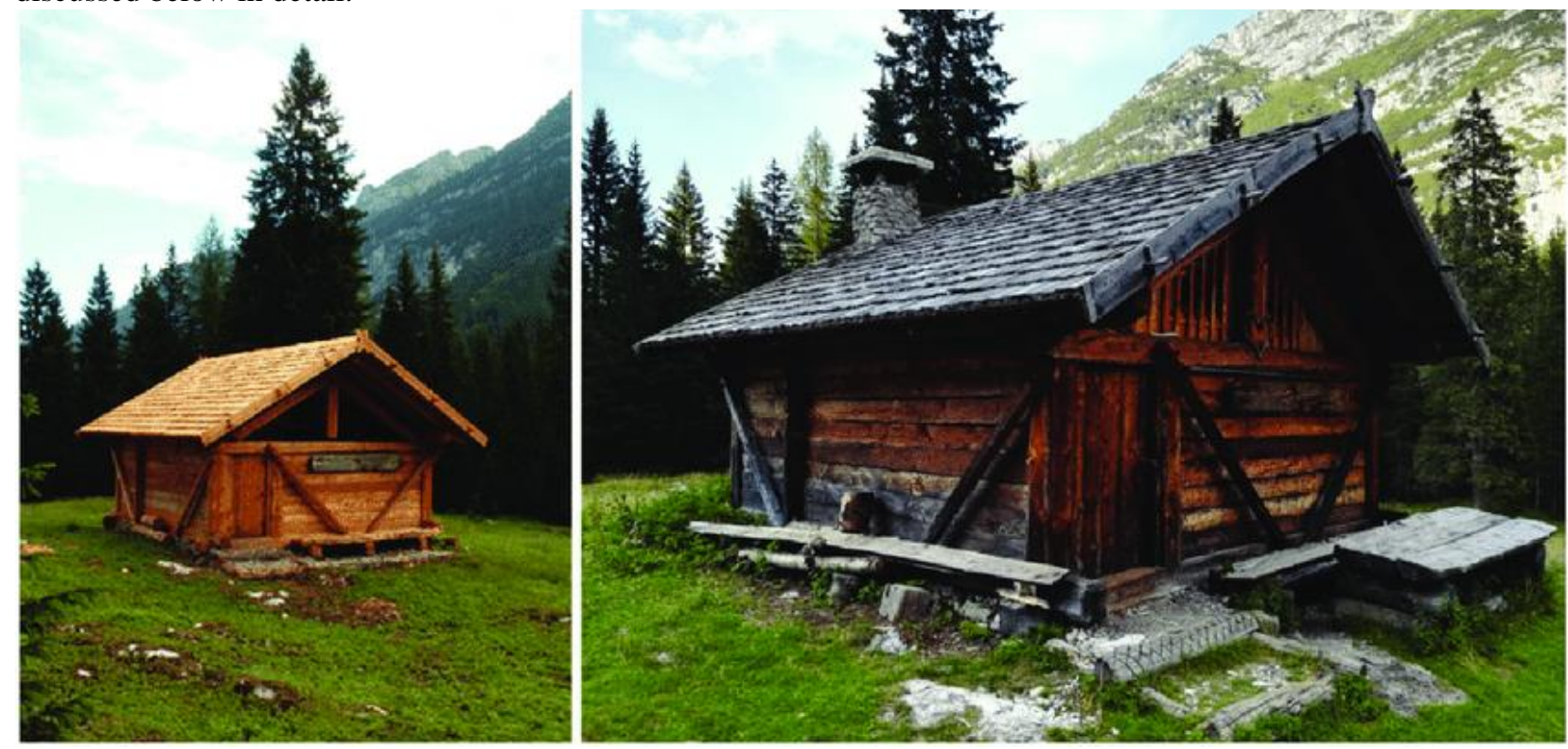

Fig. 2.6 Traditional Wooden House [19]

DOI Number: https://doi.org/10.30780/specialissue-ICACCG2020/023

Paper Id: IJTRS-ICACCG2020-023

pg. 4

@ 2017, IJTRS All Right Reserved, www.ijtrs.com 
ICACCG2020 30-31 July, 2020, Ansal University, Gurgaon, India

International Journal of Technical Research \& Science (Special Issue)

ISSN No.:2454-2024 (online)

\subsection{Certification and Rating System of Green Building}

Every developed or developing nation has its own green building guidelines which include countries like the U.S., INDIA, Japan, and Korea. There are various standards which are related to the rating system of green building. LEED or US green building standards are considered to be the best green rating system because it is certified by third-party certification. The Leadership in Energy and Environment Design (LEED) was established in the year 1998 by the U.S. Green building council. LEED guides the construction and maintenance of about 50,000 constructions around the globe. These 50,000 projects consist of 9.3 billion square feet of commercial construction place and about 115,000 residential constructions [20]. A modern society which is full of all modern equipment and buildings is made up of green building material is shown in figure 2.7. A LEED certification inspection does on a few criteria which include site sustainability, water efficiency, the priority or regions, etc. After inspection, the building is awarded LEED certifications. LEED certifications are distributed in four categories. These are LEEDcertified which is awarded on 40-49 points, LEED silver on 50-59 points, LEED gold on 60-79 points, LEED platinum on $80+$ points.

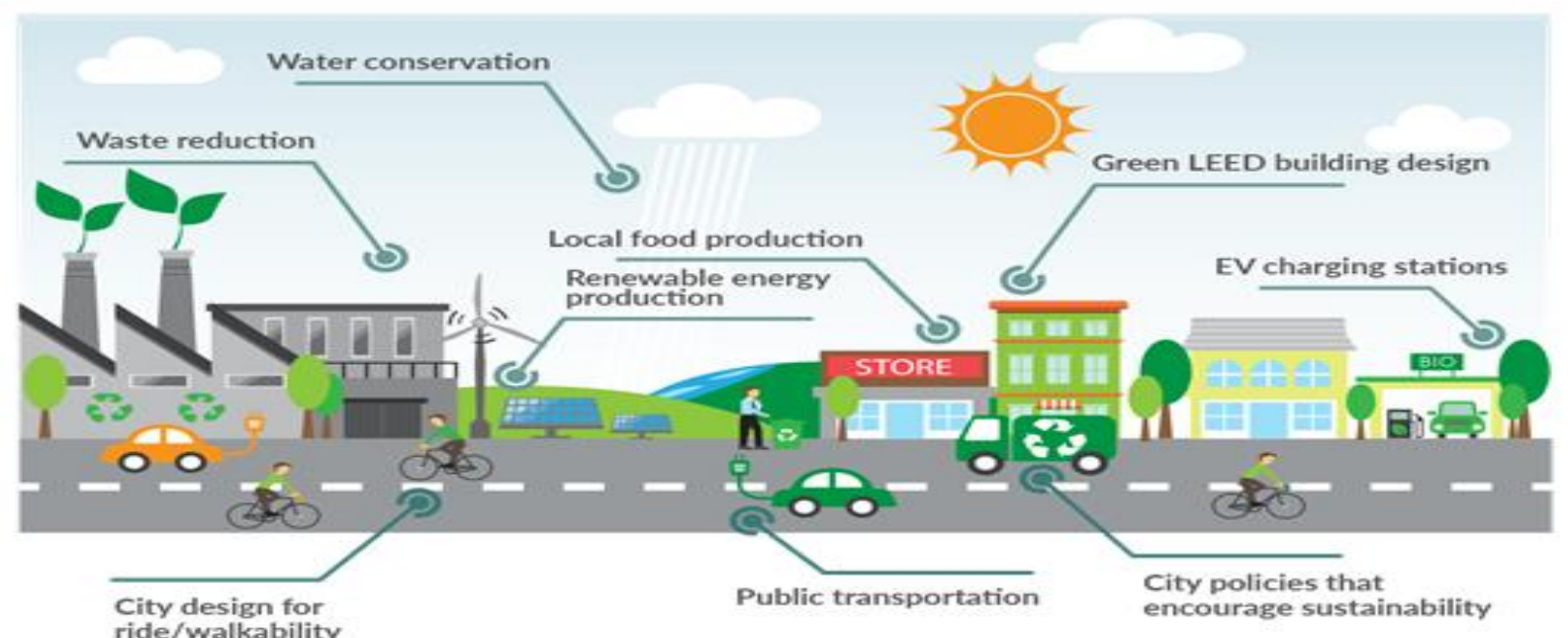

Fig. 2.7 A Model of Green Society [21]

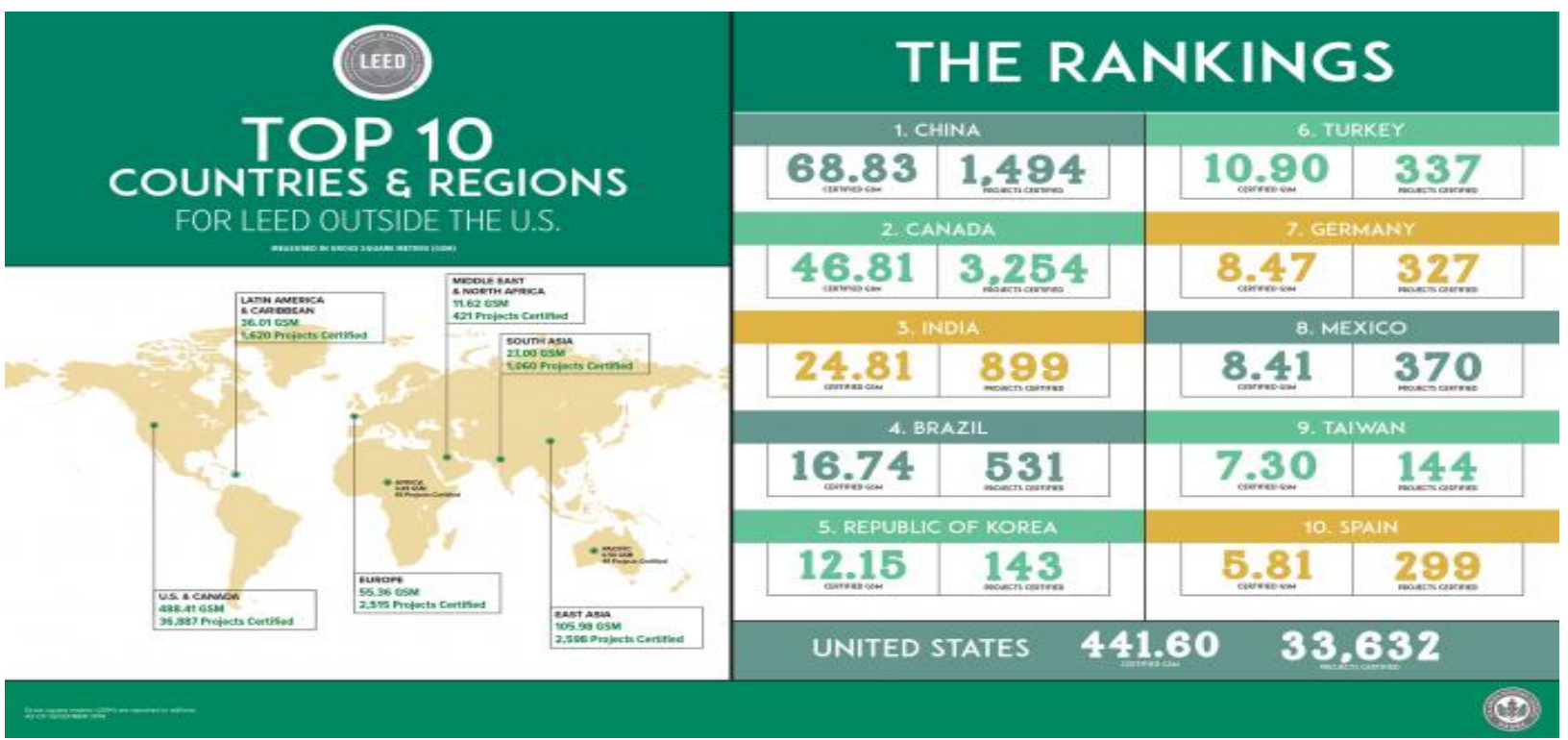

Fig. 2.8 Top 10 Countries Ranking According to LEED [22]

In Figure 2.8, Ranking issued by LEED for countries outside the U.S. discussed. China is on top with 68.83 million gross square meters (GSM) of LEED-certified space and 1,494 certified projects in that. According to this ranking, Canada is in 2nd place with about 3,254 LEED-certified buildings. According to the Canada Green Building Council (CAGBC), these buildings reduce 3.24 million tonnes of greenhouse gas emissions. These buildings also save 16.7 million eMWh of energy and 30 billion litres of water [23].

\section{CASE STUDY}

\subsection{Case Study 1}

The above study highlights the importance of energy-efficient building materials. To study their effects further a case study was carried out as per literature study containing a comparison between the studies of two different 
ICACCG2020 30-31 July, 2020, Ansal University, Gurgaon, India

International Journal of Technical Research \& Science (Special Issue)

ISSN No.:2454-2024 (online)

buildings with almost identical conditions and the differences between the effects of the green building and conventional building materials [24]. It contains parameters like temperature, humidity, noise, and light which were done at different climates, seasons which is shown in table 1.

From Table 3.1, we can see that green building has various benefits like environmental benefits, fewer wastes production, and many more. Table 1 was prepared on the basis of research which was done by Kanika et. al. in 2016 in which they created two house models for study in which one house is made from conventional building material like concrete, bricks, etc. The second house was made from green building materials like green concrete, structural insulated panels, etc. After that, they put both buildings underexposure of various conditions and came out with the conclusion that air contaminants in green building are 8 times of conventional building in the morning and reduces little bit till evening but still 5 times that of conventional one in both summer and winter conditions. In the case of temperature, green building has more temperature inside than conventional building in winters in all conditions. This condition reverses during summer as the green building has less internal temperature than a conventional building. Similarly, humidity is lesser in green buildings under all conditions. A limitation of green building was observed in the case of noise under various conditions because of a thin sheet of walls and windows. Light and air inflow were much better observed in green buildings under all conditions because it was designed for that purpose. So, we can say that it is many times better in various conditions except in the case of noise. If green materials are used in the construction of green building then many benefits can be achieved which includes Environmental benefits, health benefits, lesser waste production benefits, economic benefits, etc.

Table-3.1 Comparative Study Between Green Building and Traditional building Where GB = Green

Building; $\mathrm{CB}=$ Conventional Building [24]

\begin{tabular}{|c|c|c|c|c|c|c|c|}
\hline \multirow{2}{*}{ Parameters } & \multirow{2}{*}{$\begin{array}{l}\text { Season } \\
\text { Time }\end{array}$} & \multicolumn{3}{|l|}{ Winter } & \multicolumn{3}{|l|}{ Summer } \\
\hline & & Morning & Afternoon & Evening & Morning & Afternoon & Evening \\
\hline \multirow{3}{*}{$\begin{array}{l}\text { Air } \\
\text { Contaminants } \\
(\mathrm{ppm})\end{array}$} & GB & 0.45 & 1.21 & 1.73 & 1.28 & 1.87 & 1.36 \\
\hline & $\mathrm{CB}$ & 4.23 & 4.48 & 4.67 & 6.64 & 6.68 & 6.38 \\
\hline & Difference & 3.78 & 3.36 & 2.94 & 5.36 & 4.81 & 5.02 \\
\hline \multirow{3}{*}{$\begin{array}{l}\text { Temprature } \\
\left({ }^{\circ} \mathrm{C}\right)\end{array}$} & GB & 20 & 21.8 & 19.4 & 27.33 & 31.86 & 26.33 \\
\hline & $\mathrm{CB}$ & 12.26 & 12.28 & 11.3 & 42.66 & 48.66 & 45 \\
\hline & Difference & 7.74 & 9.52 & 8.1 & 15.33 & 16.8 & 18.67 \\
\hline \multirow{3}{*}{$\begin{array}{l}\text { Humidity } \\
(\%)\end{array}$} & GB & 56.71 & 54.01 & 56.51 & 52 & 54 & 52.66 \\
\hline & $\mathrm{CB}$ & 58 & 57 & 54.6 & 74 & 79 & 78 \\
\hline & Difference & 1.29 & 2.99 & -1.91 & 22 & 25 & 25.34 \\
\hline \multirow{3}{*}{$\begin{array}{l}\text { Noise } \\
\text { (db) }\end{array}$} & GB & 40.66 & 52.66 & 46 & 64 & 73.6 & 62 \\
\hline & $\mathrm{CB}$ & 43 & 41 & 44.66 & 64.33 & 68 & 64.45 \\
\hline & Difference & 2.34 & -11.66 & -1.34 & 0.33 & -5.6 & 2.45 \\
\hline \multirow{3}{*}{$\begin{array}{l}\text { Light } \\
\text { (Lux) }\end{array}$} & GB & 854 & 941 & 874 & 1015 & 1208 & 987 \\
\hline & $\mathrm{CB}$ & 226 & 245 & 237 & 346 & 368 & 366 \\
\hline & Difference & 628 & 696 & 637 & 669 & 840 & 621 \\
\hline
\end{tabular}

\subsection{Case Study 2}

In figure 3.1, which is a survey of green buildings in India carried out by Roy T in the year 2008 Roy T., we can see that Mumbai has the highest distribution of green buildings and Pune has less contribution towards registered buildings. Alone Mumbai has contributed 1/3 of the nation's green building. But it can be seen that it is only limited to big cities in the country. Lack of knowledge about these buildings might be a reason in small cities.

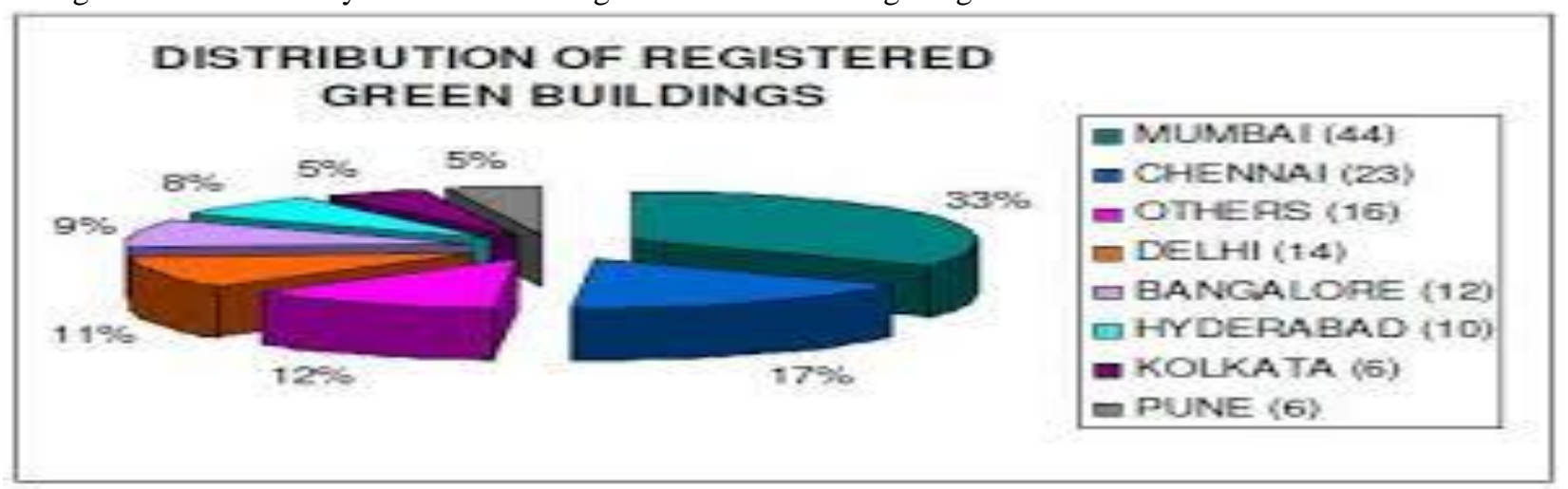

Fig. 3.1 Distribution of Registered Green Buildings [25]

DOI Number: https://doi.org/10.30780/specialissue-ICACCG2020/023

Paper Id: IJTRS-ICACCG2020-023

pg. 6

@ 2017, IJTRS All Right Reserved, www.ijtrs.com 
ICACCG2020 30-31 July, 2020, Ansal University, Gurgaon, India

International Journal of Technical Research \& Science (Special Issue)

ISSN No.:2454-2024 (online)

In Figure 3.2 which is a report of modern green structure and architecture [26], the details of a few certified buildings in India along with their rating achieved is discussed. It can be observed from figure 3.2 that for Suzlon energy building which is based in Pune and has 8,20,000 square feet built in the area achieved a platinum rating with less than $2 \%$ increase in cost. It also means that the building cost can be retrieved in 2 years only. Here, one more case of CII-Godrej with 20,000 square feet area and $18 \%$ increase in cost is observed. However, there is a huge payback year of 7 years. As in recent years, payback time is decreasing from 7 years for 20,000 sq feet in 2003 to 2 years for $8,20,000 \mathrm{sq}$ feet in 2017. So it is seen that our country has very much potential to adopt these modern materials but due to lack of knowledge of technology, awareness of this technology is still limited to bigger cities.

\begin{tabular}{|l|c|c|c|c|c|}
\hline \multicolumn{1}{c|}{ Building } & Year awarded & $\begin{array}{c}\text { Built-in Area } \\
\text { (Sqft) }\end{array}$ & $\begin{array}{c}\text { Rating } \\
\text { Achieved }\end{array}$ & $\begin{array}{c}\% \text { increase in } \\
\text { cost }\end{array}$ & $\begin{array}{c}\text { Payback } \\
\text { (Yrs) }\end{array}$ \\
\hline Cll-Godrej GBC, Hyderabad & 2003 & 20,000 & Platinum & $18 \%$ & 7 years \\
ITC Green Centre, Gurgaon & 2004 & $1,70,000$ & Platinum & $15 \%$ & 6 years \\
Wipro, Gurgaon & 2005 & $1,75,000$ & Platinum & $8 \%$ & 5 years \\
Technopolis, Kolkata & 2006 & $7,20,000$ & Gold & $6 \%$ & 2 years \\
Spectral Services Consultants & 2007 & 15,000 & Platinum & $8 \%$ & 4 years \\
Office, Noida & 2007 & 78,000 & Silver & $2 \%$ & 3 years \\
HITAM, Hyderabad & 2008 & $3,27,000$ & Platinum & $2 \%$ & 2 years \\
Kalpataru Square, Mumbai & 2010 & $8,20,000$ & Platinum & $<2 \%$ & 2 years \\
Suzlon Energy, Pune & 2010 & $2,30,000$ & Platinum & $<2 \%$ & 2 years \\
Kohinoor Hospital, Mumbai & & &
\end{tabular}

\section{CONCLUSION}

Fig.3.2 Few Rated Buildings [26]

In this paper, we discussed various green building materials, their advantages, disadvantages, and applications like, earthen materials can be used in hot areas because it provides good heat insulation and Straw bales can be used in open humid areas because of having good air inflow through pores of straw bale wall. We also discussed Insulated concrete forms and structural insulated panels as they are widely used because of its thermal insulation and U.V. ray insulation to protect it from heat rays. Wooden houses are also reviewed and considered to be good in the areas with sufficient availability of wood because of its local availability and easy installation properties. In this, various certifying agencies are also discussed and came out to the conclusion that the certification agency of the U.S.A. (USGBC) is considered to be best. From, this study, we also observed that in terms of a one-time installation price, it might be costlier but will give high returns in the long term. It is also clear that sustainability can minimize the harmful impact on nature, economy, and human health. And we saw observed that green building is beneficial in all aspects like air inflow, light, etc. but has some limitations in sound as it is made from thin sheets of windows, walls. We also saw green buildings which are also called sustainable buildings uses resources like water, solar energy, wind and materials which are less harmful than traditional materials. Green buildings can also provide benefits to buyers and builders as they are energy efficient. It was observed from the study that there are significant advantages of sustainable building materials for the construction industry. However, due to limited availability of codal provisions the large scale application of such sustainable construction methodology is prevented. Authors also observed that there is a vast scope for future research in the areas of development of codal provisions, installation techniques, and maintenance methods for developing sustainable houses.

\section{REFERENCES}

[1] Lucy Rodgers, "Climate change: The massive CO2 emitter you may not know about" URL: https://www.bbc.com/news/science-environment-46455844.

[2] Tanskanen E. (1995). Energy Saving and Modern Society Conference proceedings ECEEE Summer Studies.

[3] Lucy Wang "INFOGRAPHIC: Build Your Green Dream Home With These Eco-Friendly Alternatives to Conventional Building Materials" URL: https://inhabitat.com/infographic-build-your-green-dream-home-withthese-eco-friendly-alternatives-to-conventional-building-materials/

[4] Ding, G. K. (2008). Sustainable construction-The role of environmental assessment tools. Journal of environmental management, 86(3), 451-464.

[5] Cakmakli, A. B. (2020). Environmental Analysis of Construction Materials: Material Specifications for Green Built Environment. In Green Building Management and Smart Automation (pp. 90-110). IGI Global.

[6] Niroumand, H., Zain, M. F. M., Jamil, M., and Niroumand, S. (2013). Earth architecture from ancient until today. Procedia-Social and Behavioral Sciences, 89, 222-225.

[7] Baglioni, E., Rovero, L., and Tonietti, U. (2016). Drâa valley earthen architecture: construction techniques, pathology and intervention criteria. J. Mater. Environ. Sci, 7(10), 3499-3508.

[8] Fodde, E. (2009). Traditional earthen building techniques in Central Asia. International Journal of Architectural Heritage, 3(2), 145-168.

DOI Number: https://doi.org/10.30780/specialissue-ICACCG2020/023

Paper Id: IJTRS-ICACCG2020-023

pg. 7

@ 2017, IJTRS All Right Reserved, www.ijtrs.com 
[9] GOPI KARELIA, "BUILDING LOW COSTGREEN HOUSES SINCE 1996: ARCHITECTS BRINGS BACK MUD HOMES IN INDIA” JULY 19, 2019 URL: https://www.thebetterindia.com/189226/keralaarchitect-low-cost-sustainable-home-mudbambooindia/\#: :text=It\%20is\%20no\%20wonder\%20that,like $\% 20$ cement $\% 2 \mathrm{C} \% 20 \mathrm{glass} \% 20$ and $\% 20 \mathrm{marble}$.

[10] Bhattarai, P., Dhakal, D. R., Neupane, K., and Chamberlin, K. S. (2012). Straw bale in construction of building and its future in India. International Journal of Modern Engineering Research (IJMR), 2(2).

[11] Adam, F. M. (2018). SUITABILITY OF USING STRAW BALE AS A BUILDING MATERIAL IN SUDAN.

[12] Bhattarai, P., Dhakal, D. R., Neupane, K., and Chamberlin, K. S. (2012). Straw bale in construction of building and its future in India. International Journal of Modern Engineering Research (IJMR), 2(2).

[13] Straw Bale Construction, URL: https://www.designingbuildings.co.uk/wiki/Straw_bale_construction

[14] U.S. Department of Housing and Development, Cost and Benefits of Insulating Concrete Forms for Residential Construction, PATH, Washington, D.C., 2001.

[15] Banawi, A., and Qadir, G. (2015). A Comparative Life Cycle Assessment Modeling of External Wall Construction Systems: Case Study Residential Complex in Al-Ain, United Arab Emirates.

[16] Mullens, M. A., and Arif, M. (2006). Structural insulated panels: Impact on the residential construction process. Journal of construction engineering and management, 132(7), 786-794.

[17] Léoskool, L., and Descamps, T. (2014). Development of a structural insulated panel (SIP) with wood-based material. Experimental Research with Timber, 36.

[18] Midon, M. S., Pun, C. Y., Tahir, H. M., and Kasby, N. A. M. (1996). Construction manual of prefabricated timber house. Forest Research Institute Malaysia, 14.

[19] Petrillo, M., Sandak, J., Grossi, P., and Sandak, A. (2019). Chemical and appearance changes of wood due to artificial weathering-Dose-response model. Journal of near infrared spectroscopy, 27(1), 26-37.

[20] Shigeru Urashima "Leed Overview" LEED Presentation@ JEMAI Environment Labeling User Group Meeting 20141017 URL: https:/www.cfp-japan.jp/common/data_news/000892/1413768441.pdf

[21] Jingxi Zhao, "Think Beyond the Green Building Certification Data" URL: https://medium.com/civicanalytics/signal-3-think-beyond-the-green-building-certification-data-af65a56efe62

[22] Business Facilities "Top 10 Countries, Regions For LEED Green Building" URL: https://businessfacilities.com/2019/02/top-10-countries-regions-for-leed-green-building/

[23] "Canada ranks second in world in LEED certification: CAGBC" URL: https://www.cadcr.com/canada-rankssecond-in-world-in-leed-certification-cagbc/

[24] Kanika, S. K., Rana, K., and Dahiya, M. (2016). A comparative study on green and conventional building. International Journal of Home Science, 2(2), 338-343.

[25] Roy, T., and Gupta, A. K. (2008). Cost efficiency of Green Buildings in India. Jones Lange Lasalle Meghrag: India.

[26] MGS (Modern Green Structures and Achitecture) Green Buildings Will Be the Way of Life for Every Indian URL: https://www.mgsarchitecture.in/green-construction/interviews/258-green-buildings-will-be-the-way-oflife-for-every-indian.html. 